\title{
Upublicznianie informacji w świetle ustawy o rachunkowości
}

\author{
Making information publicly available in the light \\ of The Accounting Act
}

\author{
dr hab. Teresa Orzeszko
}

E-mail: teresa.orzeszko@ue.wroc.pl; nr orcid: 0000-0002-5587-9214

\begin{abstract}
Streszczenie
Interesariusze zgłaszają zapotrzebowanie na rozmaite informacje o podmiotach gospodarki narodowej. W celu zaspokojenia potrzeb informacyjnych odbiorców zewnętrznych oraz zminimalizowania zjawiska asymetrii informacji regulatorzy nakładają na wspomniane jednostki obowiązek upubliczniania informacji. Ponieważ znacząca część informacji powstaje $\mathrm{w}$ rachunkowości, to można sformułować tezę, że kwestia ich upubliczniania powinna być regulowana prawem bilansowym. Postawiona teza wyznacza cel badania, którym jest ocena przepisów ustawy z 29.09.1994 r. o rachunkowości (UoR) na podstawie ich analizy koncentrującej się na poszukiwaniu odpowiedzi w szczególności na następujące pytania badawcze: Czy ustawa UoR zawiera przepisy regulujące kwestie upubliczniania informacji? A jeśli tak, to jaki jest ich zakres podmiotowy i przedmiotowy? Czy przywołane przepisy zmieniały się w czasie? Czy wymagają one doskonalenia? Jakie są zasady upubliczniania informacji według UoR? Realizacja celu badania wymagała zastosowania trzech metod badawczych: analizy aktów prawnych, analizy porównawczej, metody opisowej. W rezultacie, teza badawcza została potwierdzona. Cel badań zrealizowano. Odpowiedź na pierwsze pytanie badawcze okazała się twierdząca (UoR zawiera przepisy regulujące zasady upubliczniania informacji), co uzasadniało kontynuację badań i pozwoliło sformułować kolejne wnioski stanowiące odpowiedzi na pozostałe pytania badawcze. Problematyka artykułu jest ważna, ale prawie nieobecna w literaturze przedmiotu, co uzasadniało jej podjęcie z zamiarem pomniejszenia istniejącej luki.
\end{abstract}

Słowa kluczowe: informacja, rachunkowość, transparentność, upublicznianie informacji, ustawa o rachunkowości.

\section{Summary}

Stakeholders report the need for diverse information on national economy entities. To meet external clients' information needs and minimize information asymmetry, regulators impose the obligation of making information publicly available on the aforementioned entities. As the significant part of information is generated in accounting, a thesis can be presented that the issues of making it public should be regulated by balance sheet law. The presented thesis defines the research purpose, i.e. the assessment of The Accounting Act 29/09/1994 (AA) provisions on the basis of their analysis focused on seeking answers primarily to the following research questions: Does The AA contain provisions regulating the problem of making information public? If so, what is their subjective and objective scope? Have the respective regulations changed over time? Do they require improvement? What are the rules for making information public in accordance with AA? The research objective realisation required the application of three research methods: the analysis of legal acts, comparative analysis, descriptive method. As a result, the research thesis was confirmed. The research purpose was carried out. The answer to the first research question turned out to be positive (AA contains provisions regulating the rules for making information public), which justified the research continuation and allowed presenting subsequent conclusions answering the remaining research questions. The article discusses important problems, however, practically non-existent in subject literature, which justified covering them to reduce the existing gap.

Key words: information, accounting, transparency, making information publicly available, accounting act.

JEL: D 80, M 41, M 48

Str. 2-13 


\section{Bibliografia}

Bezpłatne składanie sprawozdania finansowego do KRS po 15 marca 2018 r. (2018). Zeszyty Metodyczne Rachunkowości, (8), 464; http://www.sgk.gofin.pl/11,4967,227060,pr,bezplatne-skladanie-sprawozdania-finansowego-do-krs-po-15.html (18.05.2018).

Bushman, R. M., Piotroski, J. D., Smith, A. J. (2004). What Determines Corporate Transparency? Journal of Accounting Research, 42(2).

Business Dictionary (2018). Transparency; http://www.businessdictionary.com/definition/transparency.html (15.04.2018).

Filipowski, K. (2018). Czy publikacja sprawozdań finansowych wyłącznie drogą elektroniczną już działa. Rzeczpospolita, http://www.rp.pl/Rachun- kowosc/303219982-Czy-publikacja-sprawozdan-finansowych-wylacznie-droga-elektroniczna-juzdziala.html (31.05.2018).

Gorynia, M., Kowalski, T. (2013). Nauki ekonomiczne i ich klasyfikacja a wyzwania współczesnej gospodarki. Ekonomista, (4), 457474.

Juskowiak, M. (2018). Nowe zasady składania rocznych sprawozdań finansowych do KRS. Rzeczpospolita, http://www.rp.pl/Rachunkowosc/307049988-Nowe-zasady-skladania-rocznych-sprawozdan-finansowych-do-KRS.html (04.07.2018).

Litwińczuk, H. (1995). Prawo bilansowe. Warszawa: KiK.

Megginson, W. L. (1997). Corporate Finance Theory. New York-London-Amsterdam: Addison Wesley.

Mentel-Wyrzychowska, E. (2018). Zasady i kontrola przekazywania sprawozdań finansowych do sądu rejestrowego i urzędu skarbowego w 2018 r. Gazeta Podatkowa, nr 30 (1487), s. 14.

Micherda, B. (red.) (006). Podstawy rachunkowości. Aspekty teoretyczne i praktyczne. Warszawa: PWN.

Mingus, N. (2002). Zarządzanie projektami. Gliwice: Helion.

Misińska, D. (2001). Normy prawa bilansowego w sektorze bankowym. Zeszyty Teoretyczne Rachunkowości, 4 (60), s. $134-143$.

Muż, P. (2011). Zmiana obowiązków zwiąanych z publikacją sprawozdań finansowych, http://ksiegowosc.infor.pl/rachunkowosc/ sprawozdawczosc/132939,Zmiana-obowiazkow-zwiazanych-z-publikacja-prawozdan-finansowych.html (17.06.2018).

Napiecek, R. (015). Rachunkowość partycypacyjna, czyli koniec z monopolem na wiedzę. Studia Ekonomiczne. Zeszyty naukowe Uniwersytetu Ekonomicznego w Katowicach, nr 224, s. 151-158.

Nowe zasady przekazywania sprawozdań finansowych do KRS (2018). Biuletyn Informacyjny dla Stużb Ekonomiczno-Finansowych, nr 9 (980), http://www.sgk.gofin.pl/11,4941,226009, nowe-zasady-przekazywania-sprawozdan-finansowych-do-krs.html (13.05.2018).

Ogłaszanie sprawozdań finansowych jednostek niezarejestrowanych w KRS (2017). Rachunkowość, (1); https://rachunkowosc. com.pl/oglaszanie_sprawozdan_finansowych_jednostek_niezarejestrowanych_w_krs (dostęp 29.06.2018).

Ogłoszenie rocznego sprawozdania finansowego w Monitorze Sądowym i Gospodarczym. Zeszyty Metodyczne Rachunkowości, 10 (466), http://www.sgk.gofin.pl/11,4993,228168,pr,ogloszenie-rocznego-sprawozdania-finansowego-w-monitorze.html (21.05.2018).

Obowiązek ogłoszenia sprawozdania finansowego firmy osoby fizycznej w Monitorze Sądowym i Gospodarczym (2015). Dodatek $n r$ 32 do Biuletynu Informacyjnego dla Stużb Ekonomiczno-Finansowych, nr 33 (896), http://www.vademecumksiegowego.pl/ artykul_narzedziowa,700,0,10089,obowiazek-ogloszenia-sprawozdania-finansowego-firmy-osoby.html (15.04.2018).

Olchowicz, I. (2004). Podstawy rachunkowości - wykład (Tom I). Warszawa: Difin.

Orzeszko, T., Bąk, M. (2017). Praktyka w zakresie upubliczniania sprawozdań przez fundacje w Polsce — studium przypadku fundacji banków komercyjnych. Prace Naukowe UE we Wrocławiu, nr 479, s. 118-136.

Orzeszko, T. (2014). Polish balance sheet law vs. accounting regulations in Poland. Research Papers of Wrockaw University of Economics, (351), 50-63.

Paczuła, C. (1998). Elementy bilansoznawstwa. Część 1. Warszawa: Difin.

Piechór, M. (2017). Kto publikuje sprawozdania w Monitorze Sądowym i Gospodarczym. Rzeczpospolita, http://www.rp.pl/Rachunkowosc/306289984-Kto-publikuje-sprawozdania-w-Monitorze-Sadowym-i-Gospodarczym.html (10.04.2018).

Sawulski, J. (2015). Audyt (nie) przejrzystości finansów publicznych w Polsce. IBS Policy Paper, (2), 1-23.

Składanie i ogłaszanie rocznych sprawozdań finansowych (2017). Zeszyty Metodyczne Rachunkowości, nr 8 (440), https://www.gofin.pl/rachunko-wosc/17,1,85,213971,skladanie-i-oglaszanie-rocznych-sprawozdan-finansowych.html (15.04.2018).

Sokołowski, A., Wrzalik, A., Niedbał, R. (2016). Rola kanałów komunikacji w wielokulturowym wymiarze współdziałania przedsiębiorstw. Przedsiębiorczość i Zarządzanie, tom XVII, z. 7, cz. I, s. 467-479.

Sójka, T. (2008). Obowiązki informacyjne spółek publicznych i odpowiedzialność cywilna za ich naruszenie. Warszawa: Wolters Kluwer Polska.

Urbanek, P. (2006). Wynagrodzenia zarządu w spótkach kapitałowych. Warszawa: PWE.

Woźniak, W. (2012). Czym jest kanat komunikacyjny, https://www.experto24.pl/firma/zarzadzanie-strategiczne/czym-jest-kanalkomunikacyjny.html\#.VlYZZtIvet9 (26.04.2018).

Wrońska, E. M. Asymetria informacyjna. Potrzeba i znaczenie budowania relacji z inwestorami w procesie tworzenia wartości dla akcjonariuszy. Acta Universitatis Lodziensis. Folia Oeconomica, (262), 115-124.

\section{Akty prawne}

Ustawa z dnia 29 września 1994 r. o rachunkowości, (t.j. Dz. U. z 2018 r. poz. 395 ze zm.). Ustawa z dnia 29 czerwca 1995 r. o statystyce publicznej, (t.j. Dz. U. z 2016 r. poz. 1068 ze zm.).

Ustawa z dnia 11 maja 2017 r. o biegłych rewidentach, firmach audytorskich oraz nadzorze publicznym, (Dz. U. z 2017 r. poz. 1089 ze zm.). 
